\title{
Energy-saving biomass stove
}

\author{
Bếp tiết kiệm năng lượng dùng nguyên lý khi hóa trấu \\ Short communication
}

Hoang, Tri*

Hochiminh City University of Technology and Education, Vietnam

\begin{abstract}
This paper introduces an energy-saving biomass stove. The principle of energy-saving biomass stove is gasification. It is a chemical process, transforms solid fuel into a gas mixture, called (CO $+\mathrm{H}_{2}+\mathrm{CH}_{4}$ ) gas. Emission lines in the stove chimneys typically remain high temperatures around $90^{\circ}$ to $120^{\circ} \mathrm{C}$. The composition of the flue gas consists of combustion products of rice husk which are mainly $\mathrm{CO}_{2}, \mathrm{CO}, \mathrm{N}_{2}$. A little volatile in the rice husk, which could not burn completely, residual oxygen and dust will fly in airflow. The amount of dust in the outlet gas is a combination of unburnt amount of impurity and firewood, usually occupied impurity rate of $1 \%$ by weight of dry husk. Outlet dust of rice husk furnace has a normal size from $500 \mu \mathrm{m}$ to 0.1 micron and a particle concentration ranges from $200-500 \mathrm{mg} / \mathrm{m}^{3}$. Gas emissions is created when using energy-saving stove and they will be used as the main raw material in combustion process Therefore the $\mathrm{CO}_{2}$ emission into the environment when using the stove will be reduced up to $95 \%$ of a commonly used stove.
\end{abstract}

Bài báo giới thiệu một bếp tiết kiệm dùng năng lương sinh khối. Bếp tiết kiệm năng luợng thực hiện nguyên lý khi hóa sinh khối. Đó là một quá trình hóa học, chuyển hóa các loại nhiên liệu dạng rắn thành một dạng hỗn hợp khi đốt, gọi là khi Gas $\left(\mathrm{CO}+\mathrm{H}_{2}+\mathrm{CH}_{4}\right)$. Dòng khí thải ra ở ống khói của bếp thông thường có nhiệt độ vẫn còn cao khoảng $90^{\circ} \sim 120^{\circ} \mathrm{C}$. Thành phần của khói thải bao gồm các sản phẩm cháy của trấu, chủ yếu là các khí $\mathrm{CO}_{2}, \mathrm{CO}, \mathrm{N}_{2}$, một it các chất bốc trong trấu không kịp cháy hết, oxy du và tro bụi bay theo dòng khí. Lương bụi tro có trong khói thải chính là một phần của luợng không cháy hết và luợng tạp chất không cháy có trong củi, luợng tạp chất này thuờng chiếm tỷ lẹ 1\% trọng lương trấu khô.Bụi trong khói thải lò đốt trấu

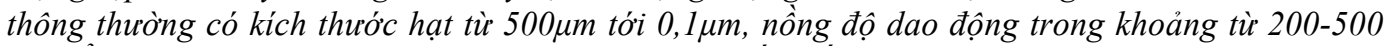
$\mathrm{mg} / \mathrm{m}^{3}$. Luợng khi thải được sinh ra khi sủ dụng bếp tiết kiệm năng luợng, sẽ được dùng làm nguyên liệu đốt cháy chính của quá trình đó. Do đó lương khi $\mathrm{CO}_{2}$ thải ra môi truờng khi sử dụng bếp tiết kiệm sẽ được giảm xuống $95 \%$ so với sử dụng bếp thuờng.

Keywords: biomass stove, energy, gasification, rice husk, $\mathrm{CO}_{2}$ emission

\section{Structure and principles}

\subsection{Structure saving stoves}

The energy-saving stove using biomass consists of the following components (Figure 1):

+ Container materials (1), (2), (3), (13), (14)

+ Tank Air Purifier (5)

+ Stove (8), (9)

+ Valve system (4), (6), (10), (12)
+ Gas Pipeline System (7)

+ Air supply fan (11)

\subsection{Principles saving stoves}

Based on the principle of incompletely burning of fuel in the hypoxia environment to produce gas for cooking, the gas generated in the combustion chamber will pass through the filter and follow the stove pipe to the kitchen. 


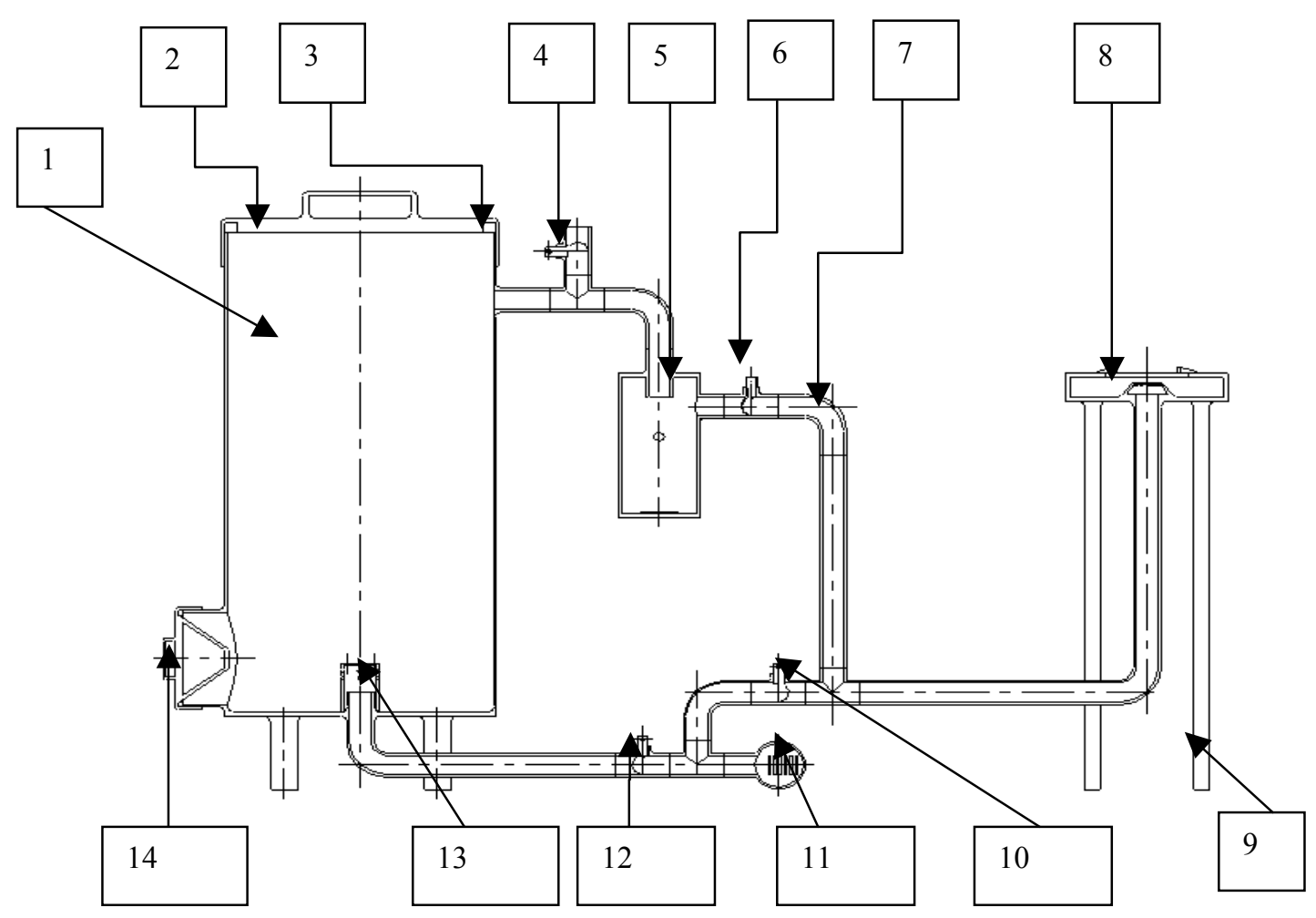

Figure 1: Energy saving stove

\section{Selection and calculation of parameters of the stove}

The main raw material is rice husk.

Table 1. Composition of elements in raw materials (\%) [1]

\begin{tabular}{|c|c|c|c|c|c|c|c|c|}
\hline \multirow{2}{*}{$\begin{array}{l}\text { Kind of } \\
\text { materials }\end{array}$} & \multicolumn{6}{|c|}{ The elemental composition } & \multirow{2}{*}{$\begin{array}{c}\text { The calorific } \\
\text { value }(\mathrm{MJ} / \mathrm{kg})\end{array}$} & \multirow{2}{*}{$\begin{array}{c}\rho \\
\left(\mathrm{kg} / \mathrm{m}^{3}\right) \\
\end{array}$} \\
\hline & $\mathrm{C}$ & $\mathrm{H}$ & $\mathrm{O}$ & $\mathrm{N}$ & $\mathrm{S}$ & ash & & \\
\hline Sawdust & 39.6 & 5.2 & 34.4 & 0.36 & 0 & 14 & 17.56 & 190 \\
\hline Rise husk & 38.5 & 5.7 & 39.8 & 0.5 & 0 & 15.5 & 15.3 & 150 \\
\hline Straw & 39.2 & 5.1 & 35.8 & 0.6 & 0.1 & 19.2 & 15.8 & \\
\hline
\end{tabular}

Table 2. Airflow components out of various fuels (\%) [4]

\begin{tabular}{cccccccc}
\hline Kind of materials & $\mathrm{CO}$ & $\mathrm{CO}_{2}$ & $\mathrm{CH}_{4}$ & $\mathrm{H}_{2}$ & $\mathrm{~N}_{2}$ & $\mathrm{HHV}$ & LHV \\
\hline Sawdust & 30.00 & 1.52 & 1.68 & 6.80 & 60.0 & 5.520 & 5.315 \\
Rise husk & 16.10 & 27.53 & 0.95 & 5.60 & 50.00 & 3.240 & 3.089 \\
Straw & 15.20 & 12.70 & 0.65 & 11.45 & 60.00 & 3.770 & 3.515 \\
\hline
\end{tabular}

HHV: maximum temperature values; LHV: minimum temperature values

\subsection{Diameter of the combustion chamber: D}

$$
D=\left(\frac{1.27 \times M}{S G R}\right)^{0.5}=\left(\frac{1.27 \times 12}{110}\right)^{0.5}=0.38 \approx 0.4(\mathrm{~m}) .
$$
where:

$\mathrm{M}$ : the mass of material contained in the chamber $(\mathrm{kg})$. $\mathrm{SGR}=110 \div 120\left(\mathrm{~kg} / \mathrm{m}^{2}\right)$ Speed gasification separate

\subsection{Height of the combustion chamber: $H$}

We have husk density in its natural state is $100 \div$ $120 \mathrm{~kg} / \mathrm{m}^{3}$. But to improve our performance of gas in the combustion chamber we have to compressed gas creates $135 \mathrm{~kg} / \mathrm{m}^{3}$.

So: every $150 \mathrm{~kg}$ of rice husk will occupy $1 \mathrm{~m} 3$. Inferred $12 \mathrm{~kg}$ of rice husk will occupy $0.08 \mathrm{~m} 3$. Inferred combustion chamber volume is $0.1 \mathrm{~m}^{3}$. $V=\frac{\pi D^{2} H}{4} \rightarrow H=\frac{4 V}{\pi D^{2}}=\frac{4 \times 0.08}{3.14 \times 0.4^{2}}=0.7 \mathrm{~m}$

With $\mathrm{V}=0: 08$, it will hold $0.08 \times 190 \mathrm{~m} 3=15 \mathrm{~kg}$ of sawdust. 


\subsection{Amount of air required to burn $1 \mathrm{~kg}$ of material}

From the combustion reaction, we can calculate the amount of oxygen necessary to infer the amount of air required.

For carbon: $\mathrm{C}+\mathrm{O}_{2} \rightarrow \mathrm{CO}_{2}$

It means: $1 \mathrm{kmol} \mathrm{C}+1 \mathrm{kmol} \mathrm{O}_{2} \rightarrow \mathrm{CO}_{2} 1 \mathrm{kmol}$

or: $\quad 12 \mathrm{~kg} \mathrm{C}+32 \mathrm{~kg} \mathrm{O}_{2} \rightarrow \quad 44 \mathrm{~kg} \mathrm{CO}_{2}$

From the reaction we see, to burn $1 \mathrm{~kg} \mathrm{C}$ need $32 / 12=$ $2.67 \mathrm{~kg}$ or $22.4 / 12=1,866 \mathrm{~m}^{3}$ of oxygen. So to burn $1 \mathrm{~kg}$ of $\mathrm{H} 2$ need $16 / 2=8 \mathrm{~kg}$ or $11.2 / 2=5.6$ $\mathrm{m}^{3}$ of oxygen.

Hence, to burn $1 \mathrm{~kg}$ of fuel which contains of $\mathrm{C}, \mathrm{H}_{2}, \mathrm{O}_{2}$, meaning to burn $38.5 \% \mathrm{~kg} \mathrm{C}, 5.7 \% \mathrm{~kg}$ of $\mathrm{H} 2$, it will need $[38.5 \% \mathrm{C} \times 1,866 \mathrm{~kg}+5.7 \% \mathrm{H} 2 \times 5.6 \mathrm{~kg}] \mathrm{m}^{3}$ oxygen. However, the available oxygen amount in the fuel is $39.8 \%$ or $39.8 \% \times \mathrm{kg}(22.4 / 32)=0.7 \times 39.8 \% \mathrm{~m}^{3}$ so the amount of oxygen needed to burn $1 \mathrm{~kg}$ of fuel is:

$$
\mathrm{V}_{\text {oxy }}=\left(\frac{38.5}{100} \times 1.866+\frac{5.7}{100} \times 5.6-0.7 \times \frac{39.8}{100}\right) \mathrm{m}^{3}
$$

In the air, the oxygen amount occupies $21 \%$ by volume so the volume of sufficient air for completion of combustion of $1 \mathrm{~kg}$ of fuel is:

$V_{k k}=V_{\text {oxy }} \times\left(\frac{100}{21}\right)=0.0889 \times 38.5+0.2666 \times 5.7-$ $0.0333 \times 39.8$

$$
\begin{aligned}
& =3.5 \frac{\mathrm{m}^{3}}{\mathrm{kgnl}} \approx 3.5 \times 1.29 \\
& =4.5 \mathrm{~kg}(\text { gas }) / \mathrm{kgnl}
\end{aligned}
$$

\subsection{Flow of air required for combustion in the combustion chamber materials}

$Q=\frac{\varepsilon \times F C R \times S A}{\delta_{a}}=\frac{0.4 \times 3.5\left(\frac{\mathrm{kg}}{\mathrm{h}}\right) \times 4.5}{1.25\left(\frac{\mathrm{kg}}{\mathrm{m}^{3}}\right)}=5.04\left(\frac{\mathrm{m}^{3}}{\mathrm{~h}}\right)$

where:

Q: gas flow in the combustion chamber $\left(\mathrm{m}^{3} / \mathrm{h}\right)$

$\varepsilon$ : equivalent rate of $0.3 \div 0.4$

FCR: The amount of material consumption $(\mathrm{kg} / \mathrm{h})$.

SA: Percentage of raw material / air $4.5 \mathrm{~kg}$ gas $/ \mathrm{kgnl}$.

$\delta_{\mathrm{a}}$ : Density of air $1,5 \mathrm{~kg} / \mathrm{m}^{3}\left(\mathrm{~kg} / \mathrm{m}^{3}\right)$.

\subsection{Gas velocity through the chaff husk}

$V_{s}=\frac{4 \times Q}{\pi \times D^{2}}=\frac{4 \times 6.3\left(\frac{m^{3}}{h}\right)}{\pi \times 0.4^{2}\left(\mathrm{~m}^{2}\right)}=40.1\left(\frac{m}{h}\right)=1.12(\mathrm{~cm} / \mathrm{s})$.

where:

VS: gas velocity through the chaff husk $(\mathrm{cm} / \mathrm{s})$

Q: Flow rate of combustion air flow $\left(\mathrm{m}^{3} / \mathrm{h}\right)$

$\mathrm{D}$ : diameter of the combustion chamber $(\mathrm{m})$

\subsection{Determination of combustion heat losses}

For the design basis for combustion air supply fan, to the extent we went calculations determining losses in the combustion chamber.

Losses were calculated:

$$
h_{L}=\xi_{L} \times \frac{V_{K}^{2}}{2} \times(1+\beta \times t), \quad \mathrm{mmH}_{2} \mathrm{O}
$$

where:

Vk: airflow velocity through the chaff, $\mathrm{m} / \mathrm{s}$

$\xi \mathrm{L}$ : coefficient of resistance of the fuel layer, depending on the standard of $\xi \mathrm{L}$ Reynollds

t: temperature inside the gasifier, ${ }^{\circ} \mathrm{C}$

With fuel is rice husk combustion temperature in the range of $700 \div 1200^{\circ} \mathrm{C}$, together with the coefficient of heat transfer by natural convection of air $\alpha=0.2 \div 0.5$.

We choose $\mathrm{t} 1=900^{\circ} \mathrm{C}$.

$\beta$ : coefficient of air temperature.

$\beta=\frac{1}{173+t} \frac{1}{K}$

Standards Reynolds

$\operatorname{Re}=\frac{v_{\mathrm{K}} \times \mathrm{d}}{\gamma}$

where:

$\mathrm{d}$ : diameter of the gas-chamber, $\mathrm{m}$

$\Upsilon$ : kinematic viscosity of the gas flow, $\mathrm{m}^{2} / \mathrm{s}$

$\mathrm{v}$ : velocity of the air flow, $\mathrm{m} / \mathrm{s}$

Looking up tables kinematic viscosity of specialized books, at a temperature of $900{ }^{\circ} \mathrm{C}$, we found the air kinematic viscosity $\mathrm{v}=185,7 \cdot 10^{-6} \mathrm{~m}^{2} / \mathrm{s}$.

$\operatorname{Re}=\frac{0.021 \times 0.4}{185.7 \times 10^{-6}}=45.4>7$

Since $\operatorname{Re}>7$ (turbulent flow) should have:

$\xi_{L}=\frac{1800}{R e}+\frac{46}{R e^{0.08}}=\frac{1800}{37.3}+\frac{46}{37.3^{0.08}}=73.5$

Then go through the obstacles in the fuel chamber:

$h_{L}=73.5 \times \frac{0.21^{2}}{2} \times\left(1+\frac{1}{273+900} \times 900\right)=2.86 m_{m} \mathrm{O}=28.1 \quad P a$

\subsection{Capacity fan}

$N_{k}=k \frac{Q \times P}{1000 \eta}=1.1 \frac{5.04 \times 28.1}{1000 \times 0.65}=0.23 k w$

where:

$\mathrm{k}$ : reserve factor -1.1

Q: Air flow $\left(\mathrm{m}^{3} / \mathrm{h}\right)$

$\mathrm{P}$ : pressure gas line $(\mathrm{Pa})$

$\mathrm{N}$ : Fan efficiency - 0.65

\subsection{Capacity of motor}

$N_{k}=\frac{N_{k}}{0.98}=\frac{0.23}{0.98}=0.23 \mathrm{kw}$ 


\section{Comparing price}

In the same amount of $9 \mathrm{~kg}$ of rice husk, the time for using traditional stoves is 57 minutes, but it is 2 hours 58 minutes for the saving stoves.

Thus, to satisfy the demand for a day according to the above calculation, we need to $9 \mathrm{~kg}$ husk for saving stove. For traditional stoves, it will need $28 \mathrm{~kg}$. It means saving stoves will reduce $19 \mathrm{~kg}$ of rice husk per day. The saving amount will be equivalent to 13.3 thousand per day if using saving stoves.

The price of a saving stove is 2,500,000 VND in the market. The payback time is about 6 months

\subsection{Operating instructions}

Input materials can be: rice husk, sawdust, firewood, straw, leaves, etc. Outputs: gasification.

\subsection{Manipulation of the stove}

Step1: Preliminary test stove Check the tightness of the pipe.

Combustion air supply valve to open, the valve remains in the closed state.

Step 2: Pour the water into the air filter until the water flow from the small drain hose Then locking back the tube to prevent water flowing out.

Step 3: Burning fire.

Put the ingredients into one-third stove.

Scratch off material from the ash removal door to make room to set up the stove.

Turn on gas supply fan at the highest level.

Proceed up the stove.

Step 4: After about 2 minutes was found with coal, raw materials continue to fill the kiln (about $10 \mathrm{~cm}$ from kiln top to create a stable air gap).

Note: the material should compress slightly on the raw rice husk, straw. For sawdust does not need compressed.

Step 5: Cover the combustion chamber. Wait approximately 3-4 minutes, open fire test valve to check the stable smoke. If the amount of smoke is a lot and stable then they can be used.

Step 6: Open the gas supply valve to the stove, ignition proceed. After strong fire open oxygen valve to adjust the flame.

Step 7: Rake out the ashes after each cooking before begin to the new batch.

\subsection{Stove Maintenance Guide}

- Checking whether the pipeline is congested by turning on the fan and opening, closing the valves. Regularly checking the smoke pipes to prevent leakage
- When you see an adhesive in the combustion chambers and dusts need cleaning immediately, to avoid smoke and flue.

- When the fan is still operating normally, but does not take the wind into the stove, turn off the fan for cleaning. - Change the water in the air filter after 2 -3 times use.

\subsection{Safety conditions while using stove}

- We need to locate the combustion chamber away from the kitchens and places where people move regularly to avoid being burned by the heat of the stove.

- When we start cooking, we need to wear protective masks to avoid the dust and smoke.

- Lock the valves carefully when not in use.

- Do not open the lid of slag when the blower switch is active to avoid burns or stove dust flew out. The flue pipe joints must be sealed.

\section{Conclusion}

The result of understanding the current use of rice husk obtained some southern delta provinces such as An Giang, Can Tho, Kien Giang, and the central provinces such as Binh Dinh, Quang Ngai, Phu Yen etc. A portion sold to people do cooking materials, compost, and most physical dump polluting the environment. There are no measures to use this natural resource in a reasonable manner.

From this we draw some conclusions as follows:

- Vietnam has a geographical location that provides favorable climate conditions for agricultural development. Due to the industrialization process, the area of agricultural land is gradually shrinking, though agriculture still plays an important role in attracting labor.

- The source of biomass energy, which is generated from the agricultural by-products in general and husk in particular, is not collected and used effectively.

- Theoretically, practical experiments show that using energy saving stove and normal stove using rice husk require the same material inputs, but the operating time of saving stove increases three times compared with normal stove's. The heat produced of saving stove is larger than normal stove.

- In terms of environmental protection, the energysaving stove plays a huge role in reducing the amount of $\mathrm{CO} 2$ emitted to the environment than the stoves using biomass energy.

\section{References}

[1] Bui, T.T. 1997. Designing husk gas furnace for the agricultural products dryers. The electrification of agriculture with industrial issues and modernization of agriculture, Agriculture Publishing House (In Vietnamese).

[2] Pham, H.L. 2007. Application of biomass gasification technology in small capacity to produce energy, Journal of Thermal Science and Technology No. 74 
(In Vietnamese).

[3] Nguyen, T.Q., Dang, T.H. 2007. Rresearch, design and manufacture the fixed coal gasification system. Journal of Thermal Technology 9 (In Vietnamese).

[4] Dao, T.Y.P. 2007. Energy demand for appropriate diet portion, Department of Nutrition, University of Medicine Pham Ngoc Thach (In Vietnamese).

[5] Ministry of Industry and Trade, International Finance Corporation, the WB 2009. Energy Conference on husks turning waste into energy and profit, November 12, 2009 (In Vietnamese).
[6] Tran, K., Nguyen, T.K. 2000. Manual processes and equipment of chemical technology, Volume 1.2. Scientific and Technical Publishing House, Hanoi (In Vietnamese).

[7] Thomas B. Reed, Agua Das 1988. Handbook of Biomass Downdraft Gasifier Engine Systems. The Biomass Energy Foundation Press, 140 pp.

[8] Alexis T. Belonio 2005. Rice Husk Gas Stove Handbook. 155 pp.

[9] Anil K. Rajvanshi 1986. Biomass Gasification India. 